Historic, Archive Document

Do not assume content reflects current scientific knowledge, policies, or practices. 


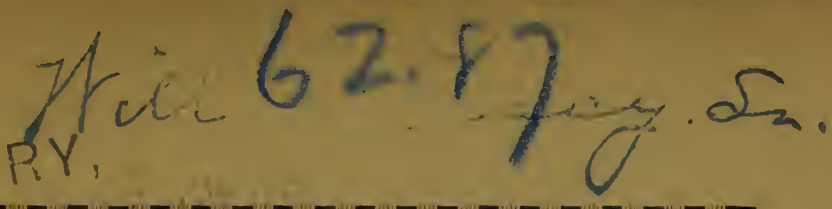

....................... SPR I N G， 1907. ,

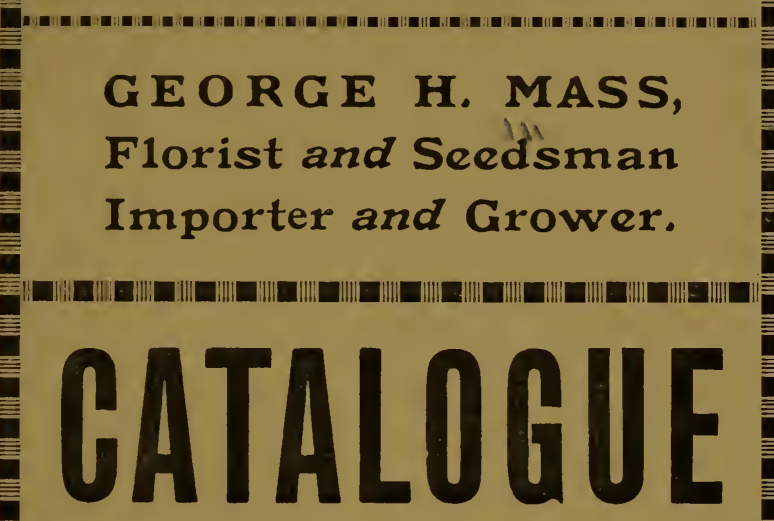

童

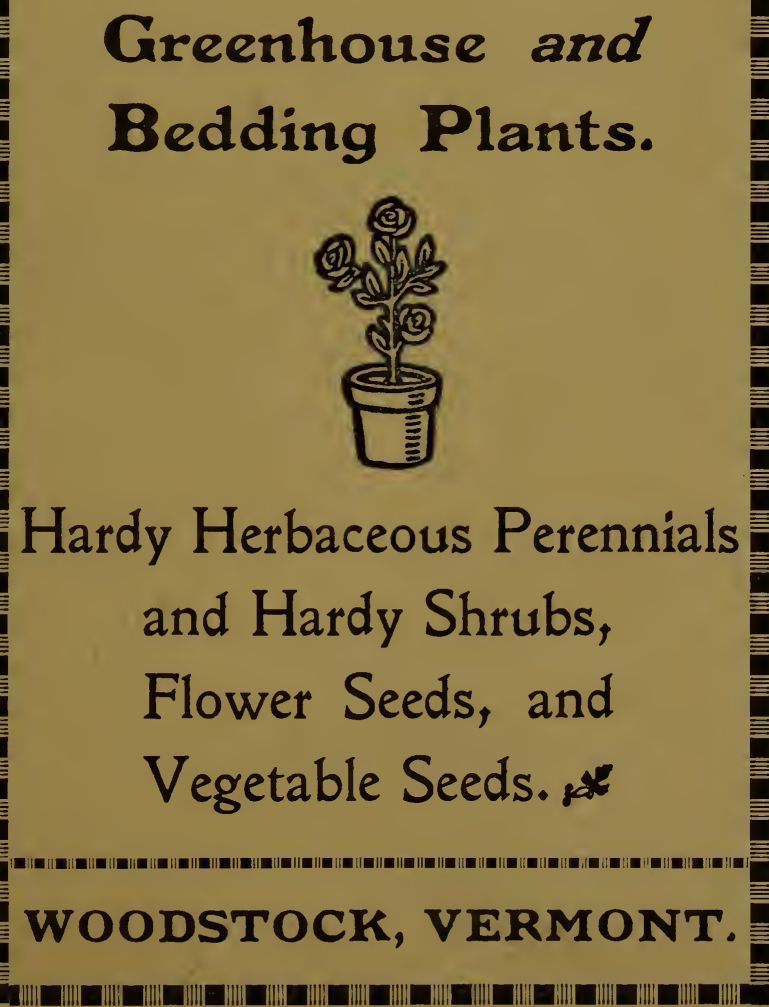




\section{MAIL ORDERS.}

GEEDS. Vegetable Seeds, in packets and (C) ounces, will be forwarded, postage paid, to any "postoffice in the United States, at prices quoted in this catalogue. On peas and beans add $5 \mathrm{c}$ per pint and roc per quart; and on corn add $4 \mathrm{c}$ per pint and $8 \mathrm{c}$ per quart, for postage.

(อLANTS. Small plants selected from this 16 catalogue will be sent by mail if so desired, postage paid; but we would advise our customers to have plants shipped by express, as larger and better plants can be sent, and extras will be added to cover express charges. We are careful in our shipment of plants. Plants offered by us are carefully grown, and are strong and healthy. We make no charge for packing, boxing, etc., and pack as lightly as possible, so as to reduce cost of carriage.

(อEMITTANCES may be made by bank draft, 1 postoffice or express money order, or registered letter. Orders from parties unknown to us will be sent C. O. D., unless accompanied by satisfactory references.

H HEN ordering seeds or plants by mail you are requested to be particular to write your name, postoffice, county and state, plainly, as delays are occasioned by such omission.

\section{Speoial Rates on Seeds}

IN PACKETS AND OUNCES.

For $\$ 0.25$ You may Select Seeds to the Amount of . . \$ $\$ 0.35$

For $\quad .50$ You may Select Seeds to the Amount of ... $\quad .65$

For 1.00 You may Select Seeds to the Amount of . . 1.30

For 2.00 You may Select Seeds to the Amount of . . 2.65

These will be sent post-paid; cash to accompany the order. Orders, however small, will have prompt attention.

GEO. H. MASS, Woodstock, Vt.

Telephone Connected with Office and Greenhouses. 


\section{Genereal Collectiön of}

\section{Greenhouse and Bedding Plants}

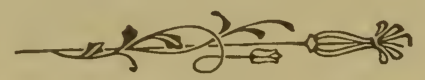

\section{ABUTILON (FLOWERING MAPLE).}

\section{DWARF EVER FLOWERING.}

A general favorite, of easy culture and continuity of bloom thronghout summer and winter months. Flowers bell shaped.

Ambigu. Very light fawn, with veins of light rose.

Boule de Neige. Fine, pure white.

Dalou. Deep crimson-maroon throughout; large bells.

Eclipse. A splendid variegated variety; especially suited for baskets and vases. IIarbled green-yellow.

Explorateur Foreau. A unique shade of glossy rosy-piuk, deep rose and rich carmine-rose in the throat.

Fra Diavola. Intense carmine, strongly toned with violet.

Fremiet. Rich yellow; large flowers, well opened.

Gen. Gallieni. Rosy-red, carmine shadings; yellow center.

Golden Bells. Yellow.

Grenadier. Rich orange-scarlet; deep yellow in center.

Gulliver. A unique shade of soft purplish-carmine.

Mercie. A very brilliant shade of glossy rosy-carmine.

Sanglant. Dark crimson, with vivid red shadings.

Savitzii. Large deep green foliage with broad white margin.

Souvenir de Bonn. Leaves marked white and green.

Price, each 10c, doz. $\$ 1.00$

\section{AGERATUM.}

Flowering through the summer and winter months; good for bedding.

Cope's Gem. Blue, six inches high.

Inimitable. New; about nine inches high. Giant flowering; lavender-blue.

Stella Gurney. Fine blue.

Each $5 \mathrm{c}$, doz. $50 \mathrm{c}$

\section{ALTERNANTHERA.}

Dwarf growing, rariegated foliage plants; excellent for bedding.

Aurea Nana. Yellow, fine for carpet bedding.

Paronychoides Major. Bright red.

Each כ̌c, doz. 30c, $100 \$ 2.50$

Vittata Hybrids.

Each $25 \mathrm{c}$ 


\section{ASPARAGUS.}

Plumosus Nanus. Leares a bright green, gracefully arched. Sprengeri. A very desirable species, especially useful to grow as a pot plant.

\section{ARAUCARIA EXCELSA.}

Norfolk Island Pine.

Each $\$ 1.00$ to $\$ 1.50$

\section{AZALEA INDICA.}

Beautiful plants for greenhouse or perlor, flowering profusely during the winter and spring months.

Each $\$ 1.00$ to $\$ 1.50$

\section{BEGONIA.}

Varieties flowering through summer and winter months.

Haageana. Strong, erect growth; the foliage of large size, flowers creamy white, shaded pink.

Manicata, Aurea Var. Large green leaves, spotted with yellow and white.

Maxii. Of free growth, foliage of a rich metallic green above and red underneath; flowers are of a bright pink color, and are borne in immensely large pendent panicles.

Metallica. Crimson and maroon. Foliage of a metallic lustre; flowers pink.

Rubra. Bright scarlet flowers.

Semperflorens Gigantea. Bright green foliage; flowers bright scarlet.

Each 10c, doz. $\$ 1.00$

\section{BEGONIA REX.}

Valuable for their grand and variously marked leaves. A fine collection of named sorts.

Each $15 \mathrm{c}$, doz. $\$ 1.50$

\section{BEGONIAS, Tuberous=Rooted.}

In Separate Colors, Single Flowering. Bright Scarlet, Deep Crimson, Pure White, Rich Pink, Bright Yellow and Orange Salmon, Dry bulbs, each 10c, doz. $\$ 1.00$

Double Flowering. Scarlet, Rose, White and Yellow

Dry bulbs, each $20 \mathrm{c}$, doz. $\$ 2.00$

\section{CALLA.}

Ethiopica. Large flower, pure white.

Each $15 \mathrm{c}$ to $30 \mathrm{c}$

Little Gem. Dwarf; flowers about half the size of the common variety.

Each $15 \mathrm{c}$

Spotted=leaf. The leaves of this variety are deep green, with numerous white spots, which give the plant a very ornamental appearance, The flowers are pure white with a 'black centre; they grow freely either indoors or out.

\section{CALADIUM ESCULFNTUM, Elephant's Ear.}

Ornamental large-leaved plants, useful for groups on lawns, requiring a rich soil.

Each $15 \mathrm{c}$, doz. $\$ 1.50$

\section{CARNATIONS.}

Boston Market. Very free-flowering, white.

Enchantress. Exquisite delicate pink, of largest size.

Prosperity. White, suffused with pink, deepening toward the center.

Queen Louise. A strong, vigorous grower, clear white. 
El Dorado. Canary yellow, tipped rosy carmine.

G. H. Crane. Clear brilliant scarlet, flowers large, very sweet.

Mrs. Thomas W. Lawson. Flowers pink, large and spreading; stems stiff;, a good grower.

Fair Maid. Delicate piuk.

Flamingo. Rich brilliant scarlet.

Mrs. Patten. White, beautifully marked with pink.

Mrs. Frances Joost. Clear pink.

White Lawson. Pure white.

Each 10c, doz. $\$ 1.00$

CANNAS, Best Standard Sorts.

Admiral Avellan. One of the best of the dark-leaved sorts; flowers deep orange.

Austria. Pure canary yellow; an orchid flowering type.

A. Bouvier. Dark crimson.

Chas. Henderson. Large crimson flowers, marked through the center with golden pencilings.

Comte de Bouchard. Golden yellow, spotted with red.

Explorateur Crampbell. Deep crimson.

Flamingo. Clear crimson.

Florence Vaughan. Yellow, spotted crimson.

Grand Rouge. Bronzy red foliage.

Mad. Crozy. Vermilion with gold border.

Musifolia. The finest foliage canna yet seen.

Paul Marquant. A peculiar shade of salmon. Very unique large flowers.

Pennsylvania. Orchid flowering; green foliage, deep scarlet blossoms.

Peachblow. White changing to rose.

Queen Charlotte. Orange-scarlet, gold band.

Robusta. Height six to eight feet with immense foliage.

Souv. de A. Crozy. Crimsou with gold band.

Each 10c, doz. $\$ 1.00$

\section{CLERODENDR0N, Balfourii.}

A beautiful greenhouse climber. with bright scarlet flowers and calyx creamy white. Very free flowering.

\section{COBAE SCANDENS.}

Each $15 \mathrm{c}$

A rapid growing vine with large, bell-shaped flowers in purple and white; will grow over 20 feet in one season.

Each 10c, doz. $\$ 1.00$

\section{CHRYSANTHEMUMS.}

In best varieties.

Each $10 \mathrm{c}$, doz. $\$ 1.00$

\section{COLEUS, Best Bedding Varieties.}

Beckwith's Gem. Center velvety maroon, bordered with red, the edge green, changing to creamy yellow at point of leaf.

Fire Brand. Bright maroon.

Golden Bedder. Golden yellow, the old original, true to name.

Golden Queen. Standard yellow.

Hero. Dark maroon, nearly black.

Lord Palmerston. Dark maroon. 
Messey. Dwarf; pearl white and silver green.

Pearl of Orange. Red and gold.

Queen Victoria. Cardinal red, with golden border.

Verschaffeltii. Standard crimson.

Each 5c, doz. 50c

Cuphea Platycentra, Cigar Plant.

Bright red flowers, tipped with white.

Each $10 \mathrm{c}$

CYPERUS ALTERNIFOLIUS.

Umbrella Palm.

Each $10 \mathrm{c}$ to $25 \mathrm{c}$

\section{CYCLAMEN PERSICUM GIGANTUM.}

Bulbous plants; succeed well in the house, flowers of good substance, lasting a long time in bloom. Colors ranging from white to pink and crimsoll. Each 25c

\section{"CACTUS" DAHLIAS.}

Countess of Lonsdale. A peculiar but pleasing blending of salmon-pink and amber. Flowers freely under all conditions.

Earl of Pembroke. Bright plum, deep and velvety.

Fire=brand. Rich, glowing vermilion, shading deeper.

Kriemhilde. The most popular dahlia today. Brilliant pink and white, the outer edge pink gradually shading to white in the center. Sturdy habit and free growth, producing fine long stemmed flowers for cutting.

Mrs. Hawkins. Rich sulphur yellow.

Mr. Moore. Deep claret.

Miss Annie Jones. Crimsoll-scarlet, early and very free.

Strahlen Krone. Cardinal-red.

Winsome. A fine creamy white.

Each $15 \mathrm{c}$, doz. $\$ 1.50$

\section{LARGE DOUBLE OR “SHOW" DAHLIAS.}

Arabella. Pale primrose, tipped old rose and lavender.

Hero. A fine shaped analine red.

John Walker. Pure white, a perfect snowhall.

John Elitch. Deep crimson.

Lottie Echford. White, spotted and striped piuk and crimson.

Mrs. Stancombe. Straw suffused amber, striped red, mottled and tipped blush white.

Miss May Lomas. Pure white, suffused witl soft rosy-larender.

Pink, Dandy. Pure pink.

Prince Bismarck. Very large, deep, strikingly rich purple.

Queen of Yellows. A beautiful clear yellow.

Snow. Pure white.

Storm King. Snow-white, a strong grower of dwarf habit.

Each 15c, doz. $\$ 1.50$

\section{POMPON DAHLIAS.}

Little Prince. Red, tipped white.

Little Naiad. Rose-lake, tipped crimson.

Snowclad. Pure white.

Sunshine. Scarlet. Perfect form, free bloomer.

Each 15c, doz. $\$ 1.50$ 


\section{PARIS DAISIES or Marguerites.}

Madame Farfaillon. Bright silvery green foliage with white Howers. Very dwarf.

Madame Gilbert. Large white petals, showing a yellow disc. Each 10c, 3 for $25 \mathrm{c}$

\section{DRACAENA.}

Fragrans. Leaves deep green.

Each 35̃

Indivisa. Long foliage, green, graceful, good for center of vases.

Each $25 \mathrm{c}$

Terminalis. Leaves brownish green, with red variegations.

Each $25 \mathrm{c}$

\section{FEVERFEW.}

Little Gem. 1)warf, flowers white, large and perfect form; double.

Each 10c, doz. $75 \mathrm{c}$

\section{India Rubber Plant.}

\section{FICUS ELASTICA.}

Each $50 \mathrm{c}$ to $\$ 1.00$

\section{FERNS.}

Very desirable plants for house or conservatory. Those offered below are among the best.

Adiantum Cuneatum. The well-known maiden hair. Each 15c

Cyrtomium Falcatum. Holly Fern; a most desirable fern for house culture; deep green foliage. Each 15c

Nephrolepis Barrowsi. In this variety we have the dense compact form of the Pierson Fern, with fronds shorter and broader, and the growth bushier and of more shapely form.

Each $50 \mathrm{c}$

Nephrolepis Exaltata Bostoniensis. Boston Sword Fern. A graceful drooping fern, the fronds of which frequently attain a length of four feet. It makes an excellent plant to grow as a single specimen.

Each $15 \mathrm{c}$; good plants $25 \mathrm{c}$; strong plants $50 \mathrm{c}$

Nephrolepis Elegantissimo. The New Plumed Fern. This is a sport from the Pierson Fern but of a more compact habit. Very desirable for all purposes. Each 35c

Nephrolepis Scottii. A condensed form of the Boston Fern with valuable characteristics added. Each $25 \mathrm{c}$ and $50 \mathrm{c}$

Nephrolepis Whitmani. The inost distinct and desirable of the crested forms of the Boston Fern. It does not revert to its original form. $\quad$ Each $75 \mathrm{c}$ to $\$ 1.00$

Polypodium Aureum. Large foliage of a distinct bluish color. Each $10 \mathrm{c}$ and $25 \mathrm{c}$

Pteris Adiantoides. (P'teris are useful for fern dishes.) Each 10c

Pteris Argyrea. Large foliage with a broad band of white through the center.

Pteris 0wrardi.

Each 10c

Pteris Palmata. Deep green foliage.

Each $10 \mathrm{c}$

Each $10 \mathrm{c}$

Pteris Serrulata. Useful for fern dishes. Each 10e

Pteris Cristata. A pretty crested feru. Each 10c

\section{FUCHSIAS, Double Varieties.}

Gloire de Marchi. Double white; a fine grower and free blooner.

Joseph Rozaine. Dark plum color, very free flowering.

Jupiter. Sepals red, corolla violet blue, of enormous size. 
Mme. Carnot. Very free flowering, flowers of very large size, tube and sepals deep coral red, corolla white veined and suffused carmine.

Molesworth. Corolla white, sepals crimson, similar to Storm King but of free growth. A fine variety, large, double.

Madame Vanderstrass. A free flowering, double white variety.

Rosain's Patrie. A strong-growing, branching plant with double white flowers produced in profusion.

White Phenomenal. Corolla pure white.

Each $10 \mathrm{c}$, doz. $\$ 1.00$

\section{FUCHSIAS, Single Varieties.}

Arabella. Deep pink and pure white.

Black Prince. Corolla and sepals carmine; free flowering.

Rose of Castile. Corolla violet, sepals white; very free flowering.

Speciosa.

Each $10 \mathrm{c}$, doz. $\$ 1.00$

\section{DOUBLE FLOWERING GERANIUMS.}

Alphonse Ricard. Bright vermilion scarlet. Fine for bedding.

Beaute Poitevine. Brilliant salmon, very large flowers.

Centaure. A beautiful rose pink. Fine bedder and good pot variety.

Champs de Neige. Pure white, double; dwarf and branching; a great favorite as a pot plant.

Comtess d'Harcourt. Pure snow white. One of the best whites.

E. H. Trego. A model of perfection. Dazzling scarlet, with soft velvety finish; semi-dwarf, robust and branching.

El Cid. A charming shade of dark velvety crimson, habit dwarf, clean and healthy. Fine pot variety. Satisfactory as a beader.

Gen. Grant. Bright vermilion scarlet, blossoms borne on long stems. A sturdy, compact grower.

Gloire de France. Light salmon pink, shading to white center. A general favorite.

Jean Viaud. Brilliant rose pink with white throat, very attractive semi-double flowers. A continual bloomer of ideal habit, strong constitution and easy of cultivation.

John Doyle. Rich scarlet. A robust grower and continuous bloomer. A universal favorite.

Mme. Barney. Pure deep pink; habit and profusion all that could be desired. Good for both pots and bedding.

Mme. Buchner. Snow-white; strong, vigorous grower with broad, fluted foliage, slightly zoned.

M. Canovas. Very dark velvety scarlet with maroon shadings. Strong grower.

Mme. Charrotte. Color clear distinct rosy salmon, dwarf; unexcelled as pot plant or bedder.

M. de Castellaine. Beautiful soft crimson, upper petals shaded with slight purple tinge ; enormous semi-double flowers borne on long stems; habit semi-dwarf, vigorous and robust.

Mme. Jaulin. Peach pink surrounded by border of white; habit dwarf, vigorous and compact. 
Miss Kendall. Dark cerise, shading to scarlet in the center. Tall, robust grower.

Mrs. Lawrence. Salmon tinted white, semi-double. Dwarf, compact habit.

M. de Montmort. Deep brilliant purple, a novel and beautiful shade, deep zoned foliage. An exceptionally striking variety.

Thomas Meehan. Color distinct brilliant rose pink, shaded lighter at the base of upper petals, dwarf ; compact, vigorous grower and abundant bloomer.

Each 10c, doz. $\$ 1.00$

\section{SINGLE FLOWERING GERANIUMS.}

C. W. Ward. Deep apricot salmon, dark green heavily zoned foliage.

Dryden. Bright soft crimson, pure white at the base of petals, giving a large white eye. Foliage slightly zoned.

Granville. Beautiful shade of rose pink, white blotches at base of upper petals. Good bedder.

Jacquerie. Brilliant crimson scarlet. Unsurpassed as a bedder.

L'Aube. Pure snow white, retaining its purity the entire season. One of the best single whites.

Mme. Bruant. Pure white reined with carmine lake, often producing a striped effect. Very attractive.

Mrs. E. Rawson. Scarlet with slight crimson shading on upper petals; deeply zoned foliage.

Fach 10c, doz. $\$ 1.00$

\section{GOLDEN AND BRONZF: GERANIUMS.}

Cloth of Gold. Leaves golden.

Happy Thought. Green, center of leaf white.

Mrs. Pollock. Margin golden, dark zone.

Each 10 c, doz. $\$ 1.00$

\section{SILVER LEAVED GERANIUMS.}

Mme. Salleroi. Leaves green, edges white, dwarf; good for ribbon beds or borders.

Each $10 \mathrm{c}$, doz. $7 \mathrm{sc}$

Mountain of Snow. Green leaf with silver edge.

Each 10 c, doz. $\$ 1.00$

\section{SCENTED GERANIUMS.}

Variegated Rose. Skeleton, Citron, Rose, Mrs. Taylor.

Each 10c

\section{DOUBLE FLOWERING IVY GERANIUMS.}

Good house plants, for baskets or vases; they crn be grown to droop or climb.

Eden Marchii. Beautiful salmon pink.

Jeanne d'Arc. Pure white; free flowering.

Leopard. Flowers clear rosy-pink the petals being heavily blazed with fiery-crimson.

Raphael. Salmon pink.

Souvenir de Chas. Turner. Large trusses; deep pink. 
Double Flowering Ivy Geraniums, (New).

Alliance. Delicate lilac white, upper petals feathered and blotched bright crimson rose; flowers semi-double.

Caesar Franck. In color a fine shade of soft crimson, with shading of tender rose at the base of petals; foliage a clear waxy green. A most desirable sort.

\section{GLADIOLUS.}

Augusta. A lovely white.

Each 2ว̃c

Brenchleyensis. Vermilion scarlet.

ฝัว. $โ ว ั \mathrm{c}$

Ceres. White flaked rose.

Isaac Buchanan. Very fine yellow.

May. White ground, pencilled crimson.

doz. $35 ّ \mathrm{c}$

doz. $35 \mathrm{c}$

Wm. Falconer. A grand pink sort.

doz. $75 \mathrm{c}$

doz. $50 \mathrm{c}$

doz. $75 \mathrm{c}$

Chieftain. Purple.

\section{HELIOTROPE.}

Snow Wreath. White.

Each $10 \mathrm{c}$, doz. $75 \mathrm{c}$

\section{CHINESE HIBISCUS.}

Large growing tropical shrubs with very glossy foliage. Blossoms average five inches in diameter and are gorgeously colored.

Aurantiaca. Large and double with orange-colored flowers.

Collerii. Flowers buff-yellow, with a crimson-scarlet base; peculiarly handsome.

Miniatus Semi=Plenus. Semi-double flowers of a brilliant vermilion-scarlet, petals waved and recurved and very handsome.

Zebrinus. Double, the outer petals scarlet, edged with yellow; inner petals are very irregular, curiously variegated with creamy yellow white.

Each 15̃c, doz. $\$ 1.50$; large plants 50c

\section{HOLLYHOCK.}

Double. White, Rose, Yellow.

Each 15̆c, doz. $\$ 1.50$

\section{HYDRANGEA.}

Hortensis. The well-known variety, pink flowers, changing to blue in soils containing iron. Facl $10 \mathrm{c}$ to $50 \mathrm{c}$

otaksa. Rosy carmine flowers, flowering when quite small. Each $10 \mathrm{c}$ to $50 \mathrm{c}$

\section{IMPATIENS SULTANII.}

Each 10c

IPOMCEA GRANDIFLORA, Moonflower.

Flowers white. Nightblooming.

Each 10c

\section{IPOMCEA LEARII, Dawnflower.}

Flowers purple.

Each $10_{c}$

\section{IVY.}

English.

Each $10 \mathrm{c}$

German. Of rapid growth, suitable for hanging baskets.

Each $10 \mathrm{c}$

\section{LEMON VERBENA.}

LOBELIA.

For lianging baskets or ribhon beds.

Each 10c

Each 10c 


\section{MADEIRA OR MIGNONETTE VINE.}

A very rapid running vine, excellent for covering outhouses or trellises; small, feathery, fragrant flowers in the fall.

Dry roots each $6 \mathrm{c}$, roots started in pots each $10 \mathrm{c}$

\section{MAHERNIA ODORATA.}

Flowers yellow, bell-shaped, sweet-scented; blooming in the winter.

Each $25 \mathrm{c}$

\section{MARANTA ZEBRINA.}

Beautiful foliage plants, leaves light green, barred with purple.

Each 50c

\section{NASTURTIUMS.}

Double Yellow. A free and vigorous grower, and continues to bloom the entire summer. Flowers are perfectly double and bright yellow.

Double Crimson. Same as the above except the flowers are a rich bright crimson. Each $5 \mathrm{c}$, doz. $50 \mathrm{c}$

\section{ORANGE OTAHEITE.}

The best of the oranges for house culture, dwarf, bushy habit, blooms freely when quite small. Each $15 \mathrm{c}$ and $40 \mathrm{c}$

\section{PEPEROMIA MACULOSA.}

Dwarf-growing, ornamental foliage plant for the window, thick fleshy leaves of green color, veined with silvery white.

Each $15 \mathrm{c}$

\section{PLUMBAG0 CAPENSIS.}

Light Blue. Very free flowering.

Alba. White.

Each $15 \mathrm{c}$

\section{PALMS.}

Valuable plants for house or conservatory; indispensable for decorating purposes.

Kentia Belmoreana. Strong-growing, with deep green foliage. Each $50 \mathrm{c}, \$ 1.00, \$ 4.00$

Kentia Forsteriana. Beautiful palm, graceful, bright green foliane.

Each $50 \mathrm{c}, \$ 1.00, \$ 4.00$

Latania Borbonica. Chinese fan palm, desirable for general cultivation. Each $50 \mathrm{c}, \$ 1.00$

\section{PETUNIAS, Double Fringed.}

Various colors.

Each 10c, doz. $\$ 1.00$

\section{PRIMROSE, Chinese.}

Various colors.

Each $10 \mathrm{c}$, doz. $\$ 1.00$

\section{ROSES, Tea, Everbiooming.}

The roses mentioned below are admirably aclapted for outdoor planting during the summer months, and with proper cultivation will furnish a continuous supply of beautiful flowers. They are also equally well adapted for forcing or house culture during the winter months.

Baldwin or Helen Gould. Of strong growth, with large, hanclsome foliage, flowers of the fullest form and of the largest size, color a bright, glowing carmine, and very free flowering. 
Duchess de Brabrant. Soft rosy flesh tint, a good bedding variety.

Etoile de Lyon. This is considered one of the finest yellow bedding roses for outside planting; it is, moreover, one of the hardiest in the tea section. It blooms freely, and every flower is a gem.

Golden Gate. A strong, healthy grower, excellent for both bedding and house culture, produces a profusion of long, pointed buds, opening to very large double roses of shell pink shading to creamy flesh on outer petals.

Gruss an Teplitz. A fine bedding rose, of free growth and beautiful foliage, flowers of bright scarlet, shading to deep rich, velvety crimson, are produced freely; very fragrant.

Ivory. Strong, vigorous, healthy growth, flowers of large size, pure white color.

Maman Cochet. One of the best new roses. The growth is vigorous, with rich, healthy foliage, the extra large flowers, produced on long stems, are deep rosy pink and are very double and fragrant.

White Maman Cochet, or Priscilla. The finest rose of the year. Like its parent, the growth is vigorous, with rich healthy foliage, producing large, fine flowers of purest white; in fact it is an exact counterpart of the beautiful Maman Cochet and all who have tried it pronounce it the finest cut flower tea rose in existence.

Perle des Jardins. Rich yellow, of large size and perfect form.

The Bride. Pure white, long buds, full and double.

The Bridesmaid. Of a rich pink shade.

Price of any of the above strong plants from four-inch pots, each $25 \mathrm{c}$, cloz. $\$ 2.50$.

American Beauty. Rich carmine-crimson. Hybrid Tea.

Kaiserin Augusta Victoria. Of a large size, creamy white, a strong grower. Hybrid Tea.

Souvenir de President Carnot. A strong, clean, healthy grower, color a delicate flesh. Hybrid Tea.

Strong plants from four-inch pots, each $25 \mathrm{c}$, doz. $\$ 2.50$

\section{POLYANTHA ROSES.}

Clothilde Soupert. The best of this class, fine for pot or outdoor planting. Color pearly white with center of soft pink.

Mosella. Canary yellow, of large size, an exceedingly free flowering perpetual rose.

Each 10c, doz. $\$ 1.00$

\section{HYBRID PERPETUAL ROSES, Hardy.}

In this list are offered some of the best of this class.

Anna de Diesbach. Clear bright carmine, full and fragrant.

Baroness Rothschild. Rich satiny pink.

Couquette des Alpes. White, tinged blush.

Gen. Jacqueminot. Brilliant scarlet crimson.

John Hopper. Bright rose, carmine center, large.

Gen. Washington. An old garden favorite, red shaded crimson and carmine, large, full and flat.

Magna Charta. Bright pink. 
Mary Dickson. White with pale flesh center, extra large flowers, of fine substance, strong, vigorous growth.

Mme. G. Luizet. Pale, satiny pink, an attractire sort.

Mrs. John Laing. Rich, satiny pink, delicious fragrance.

Paul Neyron. Very large, dark rose.

Persian Yellow. Hardy yellow rose, best of its color.

Prince C. de Rohan. Dark crimson maroon, almost black.

Ulrich Brunner. Bright cerise red, flowers large and full.

Two-years-old plants each 30c, doz. $\$ 3.00$

\section{HARDY CLIMBING ROSE.}

Crimson Rambler. Of rapid, rigorous growth, making shoots eight to ten feet in height in a single season. The flowers are produced in numerous clusters and fairly cover the plant; color brilliant crimson. Large plants 50c

\section{BABY RAMBLER.}

Mme. Norbert Levavasseur. A dwarf (bush, not climbing) form of Crimson Rambler and furthermore, everblooming. Will bloom continuously throughout the summer if planted out-of-doors. Has the same bright crimson color as the climbing Crimson Rambler, and blooms in clusters of 20 to $t 0$ flowers at one time on plants of fair size. Baby Rambler is one of the best red roses for bedding and is going to be just as popular and as extensirely planted as the climbing form has been. Each $25 \mathrm{c}$

Bonfire.

\section{SALVIA.}

Splendens. Scarlet sage.

Each 10c, doz. $75 \mathrm{c}$

\section{SANSEVIERA ZEYLANICA.}

An elegant rariegated plant well adapted for house culture. Each $50 \mathrm{c}$

\section{SWAINSONIA.}

Galegifolia Alba. Ever-blooming plant with pure white, peashaped flowers, producing sprays of from 12 to 20 flowers each.

Galegifolia Rosea. The same as the above, except the color, which is a beautiful rose.

Each $10 \mathrm{c}$

\section{TUBEROSE.}

Excelsior Pearl. Estra large bulbs.

3 for $10 \mathrm{c}$, doz. $25 \mathrm{c}$

\section{VERBENA.}

Of these useful bedding plants we offer distinct varieties. They are all of the large flowering type; the colors range through all the different shades of scarlet, purple, crimson, pink and white.

Each 5c, doz. 50c, $100 \$ 4.00$

\section{VINCA, Periwinkle.}

Very good for vases.

Major. Green leaves.

Major Variegata. Green leaves, margined white.

\section{VIOLET.}

Marie Louise. Double light purple.

California. A large single purple variety, fragrant.

Princess of Wales. Large single flowers, light purple, fragrant. 


\section{Hardy Shrubs.}

\section{BERBERIS.}

Thunbergii. Handsome foliage and solitary flowers; lowgrowing, one of the best shrubs.

Vulgaris. Upright bush and fragrant flowers, fruit deep red.

Vulgaris Var Purpurea. Purple leaved.

Each 25c

\section{CHIONANTHUS VIRGINICA, Fringe Tree.}

Foliage dark green, glossy and pure white feathery flowers.

Each $50 \mathrm{c}$

\section{HYDRANGEA PANICULATA GRANDIFLORA.}

Flowering in August and September. Each 25c, 50c, 75c

\section{LONICERA TARTARICA.}

(Bush Honeysuckle.) White and pink varieties. Each $2 \check{c}$

\section{PHILADELPHUS, Syringa or Mock Orange.}

Coronarius. Pure white flower, fragrant. Each $25 \mathrm{c}$ Gordonianus. Flowers large, white and produced late.

Each $25 \mathrm{c}$

\section{PYRUS, JAPONICA.}

Japan Quince.

Each $25 \mathrm{c}$

SPIRAEA, Meadow Sweet.

Prunifolia Fl. Pl. (Bridal Wreath.) Double pure white flowers on the entire length of the sinaller twigs. Each 25c

Opulifola Aurea. Splendid golden-leaved variety. Each 35c

Van Houttei. Foliage rich glossy green; flowers pure white, in dense clusters along the whole length of the branches, one of the finest ornamental shrubs.

Each $25 \mathrm{c}$

\section{SYRINGA, Lilac.}

Vulgaris. (Common Lilac.) Fragrant purple flowers in large clusters; one of the best.

Vulgaris Alba. (Common White Lilac.)

Each 25c

VIBERNUM OPULUS STERILIS.

(Common Snowball.) Large, white globular flowers.

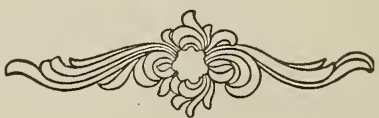




\section{Hardy Herbaceous Perennials.}

ACHILLE.

The Pearl. Flowers borne in the greatest profusion the en. tire summer ou strong, erect stems of the purest white.

Millefolia Rosea. Finely cut deep green foliage; flowers pink, in dense heads. Well worth growing, both as a border plant and for cutting.

Each 10c, doz. $\$ 1.00$

\section{ACONITUM NAPELLUS.}

(Monkshood, or Helmet Flower.) Valuable for planting under trees or in shady positions. Large dark blue flowers.

Each 10 c, doz. $\$ 1.00$

\section{ANTHEMIS, Hardy Golden Marguerite.}

This hardy Marguerite is among the most satisfactory summer-flowering perennials, succeeding in the poorest soil and blooming continuously during the entire summer.

Tinctoria. Of dense, bushy habit, with large golden-yellow flowers.

Each $10 \mathrm{c}$, doz. $\$ 1.00$

\section{BOLTONIA LATISQUAMA.}

A pretty pink flowering sọrt; very desirable.

Each $15 \mathrm{c}$, doz. $\$ 1.50$

\section{CALTHA PALUSTRIS Fl. PL.}

The double flowering Marsh Marigold, very pretty.

Each $25 \mathrm{c}$, doz. $\$ 2.50$

\section{CHRYSANTHEMUM.}

Maximum Triumph. Flowers four inches in diameter, with broad, heavy overlapping petals.

Each 15c

\section{DELPHINIUM FORMOSUM.}

(Hardy Larkspur.) This is certainly one of the handsomest and most satisfactory of all the hardy herbaceous plants aud should be planted extensively, even in the smallest garden; its long spikes of bright blue flowers are produced continually, from June until frost.

Each 10 c, doz. $\$ 1.00$

\section{DICTAMnUS, Gas Plant.}

Fraxinella. A very slowwy border perennial, forming a bush about $2 \frac{1}{2}$ feet in height, having fragrant foliage and spikes of curious red flowers.

Fraxinella Alba. Identical with the above except in color, which is pure white.

Each 15c

\section{DIELYTRA SPECTABILIS, Bleeding Heart.}

Adapted for outdoor planting, doing splendidly in semishaded positions. It bears long racemes of graceful heart-shaped pink flowers.

Eace $15 \mathrm{c}$, doz. $\$ 1.50$

\section{HARDY ASTERS.}

(Michaelmas Daisies or Starworts.) These are among the showiest of our late-flowering hardy plants, giving a 
wealth of bloom at a season when most other hardy flowers are past.

Novæ Angliæ. Large bluish purple.

Novæ Angliæ Rubra. Bright rose-colored flowers.

Snow Flake. A compact growing, very late, white flower ng variety.

Each $15 \mathrm{c}$, doz. $\$ 1.50$

\section{FUNKIA, Plantain Lily.}

Alba. Pure white lily-shaped, fragrant flowers; borne in large clusters.

Variegata. Green and white foliage, with purple flowers.

Each $15 \mathrm{c}$

\section{GAILLARDIA.}

Grandiflora. One of the showiest and most effective hardy plants, growing about two feet high, beginning to flower in June and continuing throughout the season. Large flowers of gorgeous coloring. The center is dark redbrown while the petals are variously marked with rings of scarlet, crimson, orange and vermilion, often combining all these colors in one flower.

Each 15c

\section{GYPSOPHILA PANICULATA, Baby's Breath.}

A beautiful old-fashioned perennial, possessing a grace not found in any other perennial, and attracting the eye of every one. When in bloom it forms a symmetrical mass two to three feet in height and as much through, of minute white flowers, forming a beautiful gauze-like appearance. For cutting purposes it is exquisite, especially in combination with high coloredflowers.

Each $15 \mathrm{c}$, doz. $\$ 1.50$

\section{GERMAN IRIS, Iris Germanica.}

These are neat, robust, hardy, herbaceous. early-blooming plants, with large ornamental flowers of rich and elegantly blended colors, exquisitely striped with dark violet, purple or bronzed lines, upon a lighter ground.

Assorted, each $15 \mathrm{c}$, doz. $\$ 1.50$

\section{INCARVILLEA.}

Delavayi. A fine hardy tuberous-rooted plant, very aptly called the hardy' Gloxinia. Large rose-colored trumpetshaped flowers, which last a long time, produced in clusters on stems 18 inches long. Should be protected with a covering of leaves during the winter. Each $25 \mathrm{c}$

\section{JAPANESE IRIS. ,}

These magnificent Iris are among the most beantiful of our summer-flowering plants. They commence blooming about the middle of June and continue in bloom for five or six weeks. Many of these flowers are from 10 to 12 inches in diameter, and rival the orchids in their rich colorings and markings. While the Iris succeeds in almost any soil and under any conditions, they delight in a rich, deep, wet position, and should be abundantly supplied with manure and water.

Named varieties, each $25 \mathrm{c}$, doz. $\$ 2.50$

Choice mixed varieties, each $15 \mathrm{c}$, doz. $\$ 1.50$

HEMEROCALLIS FLAVA, Yellow Day Lily.

A most useful and desirable herbaceous plant producing its 
large golden-yellow flowers during July and August in the greatest profusion; the plants grow about three feet high.

Each $15 \mathrm{c}$, doz. $\$ 1.50$

\section{HARDY GARDEN PINKS.}

Dwarf, hardy pinks, bearing double flowers of rich colors and possessed of the true clove scent; they winter better if protected. Six best varieties including white.

Each $15 \mathrm{c}$, doz. $\$ 1.50$

\section{LILIUM.}

Auratum. (Golden Banded Lily of Japan.) Each 15c Lancifolium Album.

Lancifolium Rubrum.

\section{Each 20c}

Each 15c

\section{PAEONIA, Pæony.}

Herbaceous. Assorted.

Each $25 \mathrm{c}$, doz. $\$ 2.50$

\section{PAPAVER, Poppy.}

Nudecaule. (Iceland Poppy.)

Each 10c

\section{PHLOX.}

Hybrida. Assorted, early and late flowering varieties:

Each $15 \mathrm{c}$, doz. $\$ 1.50$

\section{RUDBECKIA, Cone Flower.}

"Golden Glow." A plant that should find a place in every garden. It is of fine habit and vigorous growth, attaining a height of from four to six feet, and begins to flower early in the season and continues until late in the fall. The flowers are produced in enormous quantities on long stems, and as a cut flower for vases, etc., it has no equal.

Each $15 \mathrm{c}$

\section{STUKESIA CYANEA, The Cornflower.}

Stokes' Aster. A most charming and beautiful native hardy plant, which grows from 18 to 24 inches high, bearing freely from early in July until late in October its handsome lavender-blue centaurea-like blossoms, which measure from four to five inches across. It is of the easiest culture, succeeding in any open, sunny position, and not only is it desirable as a single plant in the hardy border, but it can also be used with fine effect in masses or beds of any size.

Each 15c

\section{HARDY CLIMBING PLANTS.}

Ampolepsis Veitchii. Boston'Ivy, or Japan Ivy. Each $25 \mathrm{c}$ Ampolepsis Quinquefolia. Common Woodbine, or Virginia Creeper.

Each $20 \mathrm{c}$

Clematis Jackmanii. Color, dark rich purple." " "Each' $40 \mathrm{c}$

Clematis Paniculata. Strong, rapid grower, flowers white and fragrant.

Each 20c

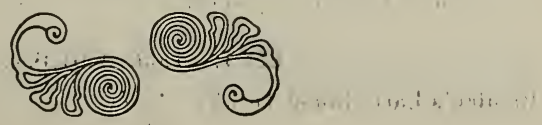




\section{Vegetable Seeds.}

\section{ASPARAGUS ROOTS.}

Conover's Colossal. 2-year-old roots, per hundred $\$ 1.00$

Palmetto. 2-year-old roots, per hundred $\$ 1.00$

BEANS, Butter or Wax Sorts-Dwarf Varieties.

Black German Wax. (Black seed.) Very early; round, yellow pods; a well-known standard sort; very popular everywhere.

pkt. 10c, qt. 25c

Burpee's Perfection Wax. Long, stringless pods; very productive and showy; a popular variety. pkt. 10c, qt. 25c

Davis' White Kidney Wax. (New.) Pods remarkably long, straight and of a handsome, waxy white color; enormously productive. Seed white. $\quad$ pkt. 10c, qt. 25c

Golden Eye Wax. Rust proof. Very hardy and prolific; a desirable and popular sort; pods flat. pkt. 10c, qt. 25c

Jones' Stringless Wax. (New.) Round stringless pods of fine quality and handsome appearance; seeds white.

pkt. 10c, qt. 30c

Wardwell's Kidney Wax. Extra early; purely wax pods, long, flat and remarkably free from rust. pkt. 10c, qt. 30c

\section{GREEN PODDED DWARF BEANS.}

Bountiful. (New.) Pods flat, green, absolutely stringless; a good trucker's sort. pkt. 10c, qt. 25c

Bush Lima, Henderson's. Beans smaller than Burpee's or Dreer's but very early and enormously productive.

pkt. 10c, qt. 35c

Bush Lima, Wood's Prolific. An improved strain of Henderson's Bush. pkt. 10c, qt. 35c

Burpee's Stringiess Green Pod. Extra early, very prolific and entirely stringless; crisp and tender, and of fine quality. pkt. 10c, qt. 25c

Horticultural Dwari. Late and productive; pods showy; great favorite in New England.

pkt. 10c, qt. 25c

Improved Early Red Valentine. Very early and one of the most popular round-pod beans.

pkt. $10 \mathrm{c}, \mathrm{qt} .25 \mathrm{c}$

\section{POLE, OR RUNNING VARIETIES.}

Dutch Case Knife. Pods long, green and flat; fine for shelling. Beans white.

$\frac{1}{2}$ pt. $10 \mathrm{c}$, pt. $15 \mathrm{c}$, qt. $30 \mathrm{e}$

Horticultural or Cranberry. Showy and excellent either as a snap or shell bean, or for cooking dry.

$\frac{1}{2}$ pt. $10 \mathrm{c}$, pt. $15 \mathrm{c}, \mathrm{qt} .30 \mathrm{c}$

Scarlet Runner. A popular variety; very ornamental, with scarlet blossoms.

pt. $10 \mathrm{c}$, pt. $15 \mathrm{c}, \mathrm{qt} .30 \mathrm{c}$

White Dutch Runner. Same habit as the Scarlet Runner; flower and bean being white.

$\frac{1}{2}$ pt. $10 \mathrm{c}, \mathrm{pt} .15 \mathrm{c}, \mathrm{qt} .30 \mathrm{c}$

\section{BEET.-Table Varieties.}

Bastian's Early Blood Turnip. Very early red variety.

pkt. $5 \mathrm{c}$, oz. $10 \mathrm{c}, \frac{1}{4}-1 \mathrm{~b} .15 \mathrm{c}, 1 \mathrm{~b} .50 \mathrm{c}$ 
Dewing's Early Blood Turnip. An improved varicty of deep blood-red color; tine form and tlavor; a favorite market sort. pkt. 5c, oz. 10c, f-lb. 15c, 1b. 50c

Eclipse Blood Turnip. Very early, round, smooth and dark leel. Has a very small top, and is one of the best for market.

pkit. 5c, oz. 10c, 1-11). 15c, 1b. 50c

Edmand's Turnip. One of the very best strains for market rardeners; small top, round, handsome and very dark recl.

pkt. $\left.5 \mathrm{c}, 0 \mathrm{z} .10 \mathrm{c}, \frac{1}{4}-11\right) .15 \mathrm{c}, 1 \mathrm{~b} .50 \mathrm{c}$

Early Egyptian Blood Turnip. One of the earliest table beets; small tops, color very dark red; flat and smooth.

pkt. 5c, oz. 10c, i-lb. $15 \mathrm{c}, 1 \mathrm{~b}$. $50 \mathrm{c}$

Swiss Chard, Silver or Sea Kale. Grown exclusively for its leaves. The middle of the leaf can be used and served like Asparagus, the rest of the leaf like Spiuach.

pkt. 5c, oz. 10c.

\section{CORN, Sweet or Sugar.}

Black Mexican. One of the sweetest and best varieties; grains black when ripe, but when in condition for the table cooks remarkably white. pkt. 5c, pt. 10c, qt. 20c

Burbank's Early Maine. Earlier than Cory ; ears lar@e, eightrowed, white grain and cob. pkt. 5c, pt, 10c, qt. 20c

Cory White Cob. A selection from Red Cory, having white keruels and white cob; early. pkt. ̌c, pt. 10c, qt. 20c

Country Gentleman. Entirely distinct; cob small, with deep, perley white kernels. pkt. $5 \mathrm{c}, \mathrm{pt}, 15 \mathrm{c}, \mathrm{qt} .25 \mathrm{c}$

Crosby. An old and popular variety, twelve and sometimes fourteen-rowed; grain thick and sweet; tiinest market sort.

pkt. $5 \mathrm{c}$, pt. $10 \mathrm{c}$, qt. $20 \mathrm{c}$

Stowell's Evergreen. The standard of quality and the bestknown variety; a favorite alike with canners and market men; remains a long time in concition suitable for boiling. pkt. ōc, pt. 10c, qt. 20c

\section{CABBAGE-( Choice Stock).}

All Seasons. Heads very deep; can be planted for early or late crop; a splendid keeper; about as early as Early Summer, forming much larger heads. pkt. $5 \mathrm{c} . \mathrm{oz} .20 \mathrm{c}$

Danish Ball Head. One of the very best winter sorts; heads round and very solid.

pkt. 5c, oz. $25 \mathrm{c}$

Early Jersey Wakefield. The most widely known and popular early variety; heads conc-shaped and rery solid. pkt. $5 \mathrm{c}$, oz. $25 \mathrm{c}$

Premium Late Flat Dutcls. A justly popular and esteemed variety ; extensively cultivated for market and family use.

pkt. $5 \mathrm{c}$, oz. $20 \mathrm{c}$

Red Dutch. The best-known of the red cabbages; much used for pickling

pkt. 5c, oz. $20 \mathrm{c}$

Winningstadt. Nincty-nine plants in every hundred warranted to head up hard and finc. One of the best for either early or late use; heads cone-shaped. pkt. 5c, oz. 30c

\section{CARROT.}

Danvers Half Long. One of the heaviest croppers; roots dark orange color, eight to ten inches in length, thick, and ending in a somewhat abrupt point; first class.

pkt. $5 \mathrm{c}$, oz. $10 \mathrm{c}, \frac{1}{4}-1 \mathrm{~b} .20 \mathrm{c}$ 
Early Scarlet Horn. A very popular sort; quick growing; deep orange in color; blunt-rooted.

pkt. $5 \mathrm{c}$, oz. 10c, $\frac{1}{4}-1 \mathrm{~b} .20 \mathrm{c}$

0xheart or Guerande. Roots short and very thick; color deep orange; fine-grained and sweet; easily dug.

pkt. 5c, oz. 10c, $\frac{1}{4}-1 \mathrm{~b} .20 \mathrm{c}$

\section{CAULIFLOWER.}

Extra Selected Dwarf Early Erfurt. The finest strain of the Erfurt cauliflower; almost as early as the Snowball; grows about 15 inches high, producing very solid, pure white heads of the very finest quality; seldom fails to form a good-sized head.

pkt. $15 \mathrm{c}$, oz. $\$ 2.00$

Henderson's Early Snowball. This is undoubtedly the finest variety ever introduced. It is the earliest and produces beautiful snow-white heads of the most delicious flavor. The seed we offer is pure and genuine.

pkt. $15 \mathrm{c}$, oz. $\$ 2.00$

\section{CELERY.}

Boston Market. Popular in the markets of Boston; a strong grower, remarkably tender and crisp. pkt. 5c, oz. $20 \mathrm{c}$

Dwarf Golden Self-Blanching. This sort is without doubt the finest early celery in cultivation. It is perfectly solid, of a fine, nutty flavor, attains a gnod size, and when blanched is of a handsome golden yellow.

pkt. $5 \mathrm{c}$, oz. $35 \mathrm{c}$

Giant Pascal. The largest variety grown, is also the best keeper; of fine, nutty flavor and very easily blanched, deservedly popular for fall and winter use.

pkt. $10 \mathrm{c}$, oz. $25 \mathrm{c}$

Golden Rose. A pink form of the Golden Self-Blanching, of the same strong, stocky habit, hardy, early and easily blanched. pkt. 10c

Improved White Plume. A well-known and perhaps the most popular variety of celery; very early, ornamental, and for quality surpassed by none. pkt. $5 \mathrm{c}, \mathrm{oz} .25 \mathrm{c}$

New Rose. The best of all the red or pink varieties, combining hardiness, solidity and keeping qualities; for crispness and fine, nutty flavor it has no superior.

pkt. $5 \mathrm{c}$, oz. $50 \mathrm{c}$

Pink Plume. Practically identical with White Plume with the added merit of the ivory white stalks being tinged with pink, rendering it most beautiful.

pkt. 10c

\section{CRESS, or Peppergrass.}

Extra Curled. A small plant having a fine, pungent flavor and used as a salad; may be cut two or three times. Oz. 5c

\section{CUCUMBER.}

Early Cluster. Fruit small and borne in pairs; light green, a great bearer. pkt. $5 \mathrm{c}$, oz. $10 \mathrm{c}$

Long Green Improved. Fine for pickling when small, good for table use when about half grown.

pkt. $5 \mathrm{c}, \mathrm{oz} .10 \mathrm{c}$

White Spine, Improved Early. The most popular strain of White Spine, and for general outdoor culture the best.

pkt. $5 \mathrm{c}$, oz. $10 \mathrm{c}$

White Spine, Peerless Improved. One of the best strains of pickling cucumbers; prolific, early, good size, full at 
both ends; color deep green, which it retains until it matures.

pkt. $5 \mathrm{c}, \mathrm{oz} .10 \mathrm{c}$

\section{DANDELION.}

Improved Broad-Leaved.

pkt. 10c, oz. $40 \mathrm{c}$

\section{EGG PLANT.}

New York Improved Purple. The leading market variety and undoubtedly the best for size, quality and productiveness.

pkt. $5 \mathrm{c}$

\section{LETTUCE, Choice Stocks.}

Big Boston. Desirable either for forcing in cold frames or open ground planting; always produces large, solid, salable heads. pkt. $5 \mathrm{c}$, oz. $20 \mathrm{c}$

Boston Market. One of the best for forcing under glass, as well as for ontside use; forms fair-sized heads, edge of leaves slightly tinged with red. pkt. 5c, oz. $15 \mathrm{c}$

Hanson Improved. Always sure to make large, handsome heads of excellent quality; outer leaves green with light veins, inner leaves white.

pkt. $5 \mathrm{c}$ oz. $15 \mathrm{c}$

Henderson's New York Cabbage. Heads eighteen inches in diameter and weighing nearly four pounds, nearly as large as a summer cabbage. pkt. $5 \mathrm{c}, \mathrm{oz} .20 \mathrm{c}$

Immensity. (New.) The largest head lettuce in the world. Tender, sweet and crisp. pkt. 5c, oz. $20 \mathrm{c}$

Simpson Black=Seeded. Leaves delicate golden yellow; for forcing or out of doors. pkt. 5c, oz. 10c

Trianon. Self-closing. pkt. $5 \mathrm{c}, \mathrm{oz} .25 \mathrm{c}$

Wonderful. Heads very large and heavy. pkt. 5c, oz. 20c;

\section{MELON-Musk Varieties.}

Emerald Gem. One of the very earliest varieties; fruit small, skin deep emerald green, flesh a handsome salmon color and very thick; flavor most delicious. pkt. $5 \mathrm{c}, \mathrm{oz} .10 \mathrm{c}$

Hackensack. Fruit large, round and flattened at the ends, deeply ribbed and heavily netted; flesh thick and of very fine flavor.

pkt. $5 \mathrm{c}, \mathrm{oz} .10 \mathrm{c}$

Long Yellow Cantaloupe. Large, long, oval and deeply ribhed; flesh light salmon yellow and very thick and sweet. Is used in its yellow state for mangoes. pkt. 5c, oz. 10c

Montreal Green Nutmeg. Flesh thick, light green, of a delicious flavor. pkt. 5 c. oz. $10 \mathrm{c}$

\section{MELON-Water Varieties.}

Citron for Preserves. The old and well-known preserving citron; seeds red. pkt. 5c, oz. 10c

Ice Cream. (White seeded.) One of the earliest rarieties and one of the best for the North; shape nearly round; light green and slightly mottled; fine flavor.

pkt. 5c, oz. 10c

Peerless. Very early and one of the best for cult vation in the North; form oval; rind mottled light green; flesh firm and sugary.

pkt. $5 \mathrm{c}$, oz. $10 \mathrm{c}$

Round Black Spanish. Round, slightly ridged and very dark green; flesh crimson, firm and very sweet; a good shipper.

pkt. $5 \mathrm{c}$, oz. $10 \mathrm{c}$ 


\section{ONION.}

White Portugal or Silverskin. A large, flat, white onion of mild and pleasant flavor; hard and fine grained, and a good keeper.

pkt. $5 \mathrm{c}$, oz. 20c, $\frac{1}{4}-1 \mathrm{~b} .75 \mathrm{c}$

Yellow Globe Danvers. Undoubtedly the best-known and most popular of all onions; the earliest yellow variety. Globular in shape, has a small top, and the most productive. pkt. $5 \mathrm{c}$, oz. $20 \mathrm{c}, \frac{1}{4}-1 \mathrm{~b} .75 \mathrm{c}$

White Sets.

ONION SETS.

Yellow Sets.

qt. $25 \mathrm{c}$

qt. $25 \mathrm{c}$

PARSLEY.

Champion Moss Curled. A standard variety, very pretty and desirable.

pkt. $5 \mathrm{c}$, oz. $10 \mathrm{c}$

Dwarf Extra Curled. Leares finely cut, very curly and bright green; desirable for either the home or market garden. pkt. $5 \mathrm{c}, \mathrm{oz} .10 \mathrm{c}$

\section{PARSNIP.}

Large Sugar or Hollow Crowned. Considered the best for general culture. The market gardener's favorite.

pkt. $5 \mathrm{c}$, oz. $10 \mathrm{c}, \frac{1}{4}-1 \mathrm{~b} .20 \mathrm{c}$

Long Smooth White. A standard variety with long, smooth, white roots. pkt. $5 \mathrm{c}$, oz. $10 \mathrm{c}, \frac{1}{4}-1 \mathrm{~b} .20 \mathrm{c}$

\section{PEAS, Extra Early Dwarf Varieties.}

Bliss' American Wonder. Earliest dwarf wrinkled sort; height three-fourths foot. $\frac{1}{2}-$ pt. $10 \mathrm{c}$, pt. $15 \mathrm{c}, \mathrm{qt} .30 \mathrm{c}, \mathrm{pk} . \$ 2.00$

Nott's Excelsior. Very early; wrinkled pods always well filled; finest quality. Height $1 \frac{1}{4}$ feet.

$\frac{1}{2}$-pt. $10 \mathrm{c}$, pt. $15 \mathrm{c}, \mathrm{qt} .30 \mathrm{c}$, pk. $\$ 2.00$

\section{Second Early Varieties.}

Dwarf Champion. Wrinkled. This pea gives universal satisfaction; very productive; peas large; fine flavor: height two feet.

$\frac{1}{2}$-pt. $10 \mathrm{c}$, pt. $15 \mathrm{c}, \mathrm{qt} .25 \mathrm{c}, \mathrm{pk} . \$ 1.50$

Heroine. Wrinkled. A grand pea; large pocls, containing eight to nine large peas of finest flavor. Height $2 \frac{1}{2}$ feet.

$\frac{1}{2}$-pt. $10 \mathrm{c}$, pt. $15 \mathrm{c}, \mathrm{qt} .25 \mathrm{c}, \mathrm{pk} . \$ 1.50$

Telephone. Wrinkled. Pods very large, filled with immense peas of first-class quality; one of the finest yet introcluced. Height $4 \frac{1}{4}$ feet.

$\frac{1}{2}$-pt. $10 \mathrm{c}$, pt. $15 \mathrm{c}, 9$ t. $30 \mathrm{c}$, pk. $\$ 2.25$

\section{Late Variety for General Crop.}

Champion of England. Wrinkled. One of the richest, bestflavored peas; well known and popular. Hoisht 5 feet.

支-pt. $10 \mathrm{c}, \mathrm{pt} .15 \mathrm{c}, \mathrm{qt} .25 \mathrm{c}, \mathrm{pk} . \$ 1.25$

\section{PEPPER.}

Large Bell or Bull Nose. A farorite pickling sort; it is early, large, mild and thick-skinned; color red.

pkt. $5 \mathrm{c}$

Ruby King. The best and most profitable mild red pepper for market or family use; sweet and mild; largest size.

pkt. כe

\section{PUMPKIN.}

Sweet or Sugar. A small, round and very prolific variety; 
skin and flesh deep orange yellow; very fine grained. The pie pumpkin of New England.

pkt. $5 \mathrm{c}, 0 \mathrm{z}, 10 \mathrm{c}, \frac{1}{4}-1 \mathrm{~b}, 20 \mathrm{c}$

\section{RADISH.}

French Breakfast. Pink color, olive shaped, white tipped; popular everywhere.

pkt. 5̌c, oz. 10c

Turnip, Early Scarlet. A well-known variety; very quick grower.

pkt. $5 \mathrm{c}$, oz. $10 \mathrm{c}$

\section{RHUBARB.}

Victoria. Stalks and leares of immense size. pkt. 5̌c, oz. 20c

\section{SAGE.}

Sage. A highly aromatic herb; most useful of all. pkt. 5 c SALSIFY, or Vegetable 0yster.

Mammoth Sandwich Island. Roots three times the size of ordinary salsify, and of more agreeable flaror. Pure white.

pkt. $10 \mathrm{c}$, oz. $15 \mathrm{c}$

\section{SPINACH.}

Long Standing Thick Leaved. Stands longest before running to seed; dark green. pkt. $5 \mathrm{c}$, oz $10 \mathrm{c}, \frac{1}{4}-1 \mathrm{~b} .15 \mathrm{c}$

Thick Leaved Round. Large, thick, dark green, crumpled leaves which remain a long time before going to seed.

pkt. 5c, oz. $10 \mathrm{c}, \frac{1}{4}-1 \mathrm{~b} .15 \mathrm{c}$

\section{SQUASH.}

Improved Hubbard. The well-known and standard late variety. pkt. 5c, oz. 10c

Summer Crookneck. Summer variety; small crookneck, skin bright yellow; early and productive. pkt. 5c, oz. 10c

\section{TOMATO.}

Beauty. (Liringston's.) Large, smooth, pinkish red; thick flesh, regular form.

pkt. $5 \mathrm{c}$

Crimson Cushion. Bright crimson; extra large and very handsome.

pkt. 5̆c

Dwarf Champion. Distinct in foliage and habits of growth, being compact and upright; fruit smooth, early and purplish red.

pkt. $5 \mathrm{c}$

Earliana. Claimed to be the earliest; large, smooth red; very prolific.

pkt. $5 \mathrm{c}$

Favorite (Livingston's.) Large, smooth, productive and a good shipper. pkt. 5c

Golden Queen. Yellow, ripens early, is large sized, smooth and solid; excellent quality. pkt. 5c

New Stone. Vine vigorous and productive. Fruit round, very large, very deep red in color and astonishingly heavy.

pkt. $5 \mathrm{c}$

Perfection. (Livingston's.) A standard sort; early, regular and productive. Blood red, has few seeds. pkt. 5c

Ponderosa. Very large, solid and of good flavor; bright red; very few seeds.

pkt. $5 \mathrm{c}$

Trophy. Extra selected from perfect specimens of this old farorite, rendering it free from the corrugations of tha old strains. 


\section{TURNIP.}

Red or Purple Top Strap Leaved. The most widely cultivated and best known variety. It is round and flat, white on the bottom and a reddish purple above ground, and a very quick grower. It is one of the finest table varieties. pkt. 5c, oz. 10c, $\frac{1}{4}-1 \mathrm{~b} .20 \mathrm{c}$

\section{RUTABAGA, or Swedish Turnip.}

Improved American Purpletop. This strain is of American origin. Roots are of great size, yellow fleshed and purple crown; one of the most desirable varieties.

pkt. $5 \mathrm{c}$, oz. $10 \mathrm{c}, \frac{1}{4}-\mathrm{lb} .20 \mathrm{c}$

White Sweet German. The sweetest, mildest flavored and finest grained turnip for table use; solid as a stone, and will remain in this condition until spring if properly cared for; has no equal as a winter turnip.

pkt. 5c, oz. 10c, $\frac{1}{4}-1 \mathrm{~b} .20 \mathrm{c}$

\section{Vegetable Plants.}

\section{CABBAGE PLANTS.}

Jersey Wakefield and Winningstadt, early plants,

per hundred $65 \mathrm{c}$

\section{CAULIFLOWER.}

Snowball, early plants,

doz. 20 , hundred $\$ 1.00$

Snowball, late plants,

doz. $12 \mathrm{c}$, hundred $75 \mathrm{c}$

\section{LETTUCE PLANTS.}

Best varieties, ready in early spring, doz. 10c, hundred 50c

\section{PEPPER PLANTS.}

per doz. 20c

\section{CELERY PLANTS.}

White Plume, Golden Self-Blanching, Boston Market, New Rose, Giant Pascal, ready in June, per hundred 75c

\section{TOMATO PLANTS.}

Large size, 5-inch pots,

Each $10 \mathrm{c}$, per doz. $\$ 1.00$

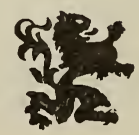




\section{Genera1 List of}

\section{Choice Flower Seeds.}

The following list contains a selection of the best and most popular Annual, Biennial and Perennial Flowers. Flower Seeds in Packets are sent free by mail at catalogue prices.

\section{ASTER.}

Giant Comet. Finest mixed.

Giant Comet. White, Crimson, Salmon Rose, Lavender. pkt. $10 \mathrm{c}$

Late Flowering. Finest mixed. each $10 \mathrm{c}$

Late Flowering. Semple's White, Shell Pink, Purple, Lavender, Crimson. exch

Perfection. Pæony-flowered; finest mixed.

Perfection. Purple, Rose, White, Queen's Scarlet.

Queen of the Earlies. Finest mixed. each $10 \mathrm{c}$

Queen of the Earlies. White, Rose Pink. each 10c

Victoria. Finest mixed. 10c

Victoria. Peachblossom Pink, White, Sky Blue, Purple.

$$
\text { each } 10 \mathrm{c}
$$

\section{ALYSSUM.}

Flowers white. Valuable for beds and edges. Alyssum. Sweet, White, eight inches high.

Alyssum. Sweet, Dwarf White.

pkt. $5 \mathrm{c}$

BALSAM, Double.

Double Camellia Flowered. Mixed, choice.

pkt. $5 \mathrm{c}$

CALENDULA.

Orange King.

pkt. $5 \mathrm{c}$

Lemon King.

$$
5 \mathrm{c}
$$

CALLIOPSIS, or Coreopsis.

Large Flowering. Mixed.

pkt. $5 \mathrm{c}$

\section{CANDYTUFT.}

Empress. White.

pkt. $5 \mathrm{c}$

Mixed Colors.

\section{CARNATION.}

Giant Marguerite. Double, mixed. Flowers in four months from day of sowing.

CELOSIA PLUMOSA, or 0strich=Plume Coxcomb.

Garden annual two to three feet high, producing large, graceful plumes.

Plumosa Magnifica. Mixed.

pkt. $15 \mathrm{c}$

CENTAUREA, Cyanus (Bachelor's Button.)

Blue.

Mixed.

pkt. $5 \mathrm{c}$ 


\section{COBAEA SCANDENS.}

Well=known Climber. Two colors, Blue and White. pkt. 5c

\section{CONVOLVULUS.}

Major. (Morning Glory) mixed.

pkt. $5 \mathrm{c}$

cosmos.

Early Flowering. Mixed.

pkt. $5 \mathrm{c}$

\section{DIANTHUS.}

Chinensis. Fl. pl. (Double China or Indian Pink), one foot, mixed.

Heddewigii. Fl. pl. (Double Japan Pink), mixed.

Laciniatus. Large double fringed flowers, mixed.

eSCHSChOLTZIA, California Poppies.

Californica. Yellow.

pkt. $5 \mathrm{c}$

Finest Mixed.

\section{HOLLYHOCK.}

I)ouble White, Double Yellow, Double Deep Rose. pkt. 10c Double Mixed.

Single Mixed.

\section{LARKSPUR.}

Tall Rocket. Mixed.

\section{LOBELIA.}

White and Blue.

pkt. $5 \mathrm{c}$

\section{MARIGOLD.}

Double French. Mixed, yellow, brown and crimson colors, one foot.

Pride of the Garden. Immense flowers, very double, 8 to 10 inches in circumference, color deep golden yellow; 15 to 18 inches high.

Single Flowering Little Brownie.

\section{MIGNONETTE.}

Machet Perfection. Large cone-shaped heads, a fine mignonette.

Mignonette, Large Flowering. Sweet scented.

Bird's Mammoth. Long, large spikes, well filled.

\section{MYOSOTIS, Forget=me=not.}

Palustris. Dark blue flowers, 6 to 12 inches.

Alpestris. Blue or white, one foot high,

\section{NASTURTIUM.}

Tall or Climbing.

Mixed. Many colors. pkt. $5 \mathrm{c}$, oz. 10c, $\frac{1}{4}-1 \mathrm{~b} .35 \mathrm{c}$ Dwarf.

Mixed. Many colors. pkt. $5 \mathrm{c}$, oz. $10 \mathrm{c}, \frac{1}{4}-1 \mathrm{~b} .35 \mathrm{c}$ Dwarf, in Separate Colors.

Brilliant. Glistening scarlet, dark foliage.

Coccineum. Light scarlet. pkt. 5c, oz. 20c

Empress of India. Crimson, dark foliage. pkt. $5 \mathrm{c}$, oz. $20 \mathrm{c}$ Golden King. Golden, maroon blotches. pkt. 5c, oz. 20c pkt. $5 \mathrm{c}$, oz. $20 \mathrm{c}$ 
(Nasturtiums, Dwarf, Continued.)

King Theodore. Garnet, dark foliagre.

pkt. $5 \mathrm{c}, \mathrm{oz} .20 \mathrm{c}$

Pearl. Creamy white.

Prince Henry. Cream, scarlet, wine. pkt. $5 \mathrm{c}, \mathrm{Oz}, 20 \mathrm{c}$

Rose.

Ruby King. Ruby red. pkt. $5 \mathrm{c}, \mathrm{oz} .20 \mathrm{c}$ pkt. $5 \mathrm{c}$, oz. $20 \mathrm{c}$ pkt. $5 \mathrm{c}, 0 \mathrm{z} .20 \mathrm{c}$

Mixed from above varieties. pkt. $5 \mathrm{c}, 0 z .15 \mathrm{c}$

Tall or Climbing, in Separate Colors.

Atropurpureum. Rich crimson.

pkt. 5c, oz. $20 \mathrm{c}$

Coccineum. Orange scarlet.

Heinemanni. Chocolate.

King Theodore. Crimson, dark foliage. pkt. $5 \mathrm{c}$, oz. $20 \mathrm{c}$

Luteum. Bright yellow.

Pearl. Creamy white.

Rose.

Scheuerianum. Crimson, dark foliage.

Mixed from above varieties. pkt. $5 \mathrm{c}, 0 \mathrm{z} .20 \mathrm{c}$ pkt. $5 \mathrm{c}$, oz. $20 \mathrm{c}$ pkt. $5 \mathrm{c}, \mathrm{oz} .20 \mathrm{c}$ pkt. $5 \mathrm{c}$, oz. $20 \mathrm{c}$ pkt. วัc, oz. $20 \mathrm{c}$ pkt. 5̌c, oz. $20 \mathrm{c}$ pkt. $5 \mathrm{c}, \mathrm{oz} .15 \mathrm{c}$

\section{NICOTIANA.}

Affinis. (Tuberose-fluwered Tobacco.) Sweet scented, pure white tubular flowers, blooming continually; annuals.

Sanderæ. The new carmine tuberose-flowered tobacco. pkt. 5̌c pkt. 10c

\section{PANSY.}

Bugnot's Superb. Mixed.

German. Finest mixed.

pkt. $10 \mathrm{c}$

Giant Trimardeau. Mixed.

$10 \mathrm{c}$

Good Mixed.

$10 \mathrm{c}$

5̌c

\section{PETUNIA.}

Fine Mixed. Single rarieties.

pkt. $5 \mathrm{c}$

Large Flowering. Fringed, superb strain, single.

$25 \mathrm{c}$

\section{PHLOX DRUMMONDI.}

One Foot; Large Flowering, in Separate Colors.

Pure White, White with claret eye, Blood Purple, Brilliant Rose, Brilliant Scarlet, Yellow with garnet eye.

Mixture of above colors. pkt. $10 \mathrm{c}$ $10 \mathrm{c}$

\section{POPPY.}

Giant. Mixed.

Double Annual Varieties.

Pæony Flowered. Mixed.

pkt. ร̌c

Featherball. White, Pink, Scarlet, Orange-rose. Mixed. 5c Single Annual Varieties.

Empress of China. White, scarlet edged.

Glaucum. The scarlet tulip poppy.

pkt. $5 \mathrm{c}$

English Scarlet Field.

Shirley. Mixed.

Iceland. Mixed. 


\section{PORTULACA,}

Large double-flowering; mixed.

Large single-flowering; mixed.

pkt. 5c

RICINUS, (Castor Oil Bean).

Borboniensis. Immense foliage of violet color.

pkt. $5 \mathrm{c}$ Sanziboriensis. Mixed, including light and dark green, brown and brownish purple leaves.

pkt. 5c

SALVIA, Scarlet Sage.

Bonfire.

pkt. $10 \mathrm{c}$

Splendens.

\section{STOCKS TEN WEEKS.}

Large Flowering. Double, Pure White, Lavender,

Blood Red, Canary Yellow, Bright Rose, each, pkt. 10c Mixed Colors.

\section{SUNFLOWER.}

Double Californica.

pkt. $5 \mathrm{c}$

Giant Russian. Flowers 18 to 20 inches across.

Macrophyllus Giganteus. Six feet high.

Mammoth Russian. The standard large growing variety.

\section{SWEET WILLIAM.}

Single. Mixed.

pkt. $5 \mathrm{c}$

Double. Mixed.

Perfection. Double, mixed.

\section{VERBENA.}

Mammoth, or Large Flowering. Scarlet, Purple, White, Mixed.

\section{ZINNIA.}

Double Dwarf. White, Orange, Salmon-rose, Crimson.

Double Dwarf. Mixed colors. 


\section{SMEET PEAS.}

A Selection of New and Best Standard Varieties.

Aurora. Striped orange-salmon on white ground.

Blanche Burpee. Pure white of superior substance; flowers large and finely forned.

Blanche Ferry. Very popular; pink and white.

Extra Early Blanche Ferry. Ten days earlier than Blanche Ferry.

Captain of the Blues. Standard purple-mauve; wings pale blue.

Coccinea. Pure cerise.

Coquette. Primrose yellow shaded with lavender.

Countess of Latham. Delicate pink.

Dainty. White edged with pink.

Duke of Westminster. Standard clear purple; wings purple with tint of violet.

Earliest of All. Standard rose; wings white tinged with pink.

Emily Henderson. A new pure white, largest of all and an excellent variety.

Firefly. Brilliant scarlet.

Hon. Mrs. E. Kenyon. Primrose color.

Katherine Tracy. Brilliant pink:

Lady Grisel Hamilton. Pale lavender-blue.

Lovely. Soft shell pink.

Miss Willmott. Standard orange-pink; wings rose with tint of orange.

Mrs. Eckford. Delicate shade of primrose-yellow.

Mrs. Sankey. One of the largest and best pure white.

Navy Blue. Splendid dark blue.

New Countess. Lavender.

Othello. Deep maroon; fine.

Painted Lady. Old, popular; pink and white.

Prima Donna. Lovely shade of soft pink.

Prince of Wales. Bright rose; self colored.

Stanley. Deep maroon; flowers large and of fine form.

Stella Morse. Rich primrose, flushed pink.

Prices for Any of the Above=named Varieties, Postage Paid:

Packet 5c, ounce $8 \mathrm{c}$, quarter-pound $20 \mathrm{c}$.

Six packets of named varieties.

Twelve packets of named rarieties,

Twenty-four packets of named varieties,

\section{Smeet Peas in Mixture.}

Eckford Mixture. This mixture contains over 20 varieties, many novelties. $\frac{1}{2}-\mathrm{oz} . \mathrm{pkt}, 5 \mathrm{c}, \mathrm{oz} .8 \mathrm{c}, \frac{1}{4}-\mathrm{lb}, 20 \mathrm{c}$

Fine Mixture. All colors. $\quad$ oz. $5 \mathrm{c}, \frac{1}{4}-1 \mathrm{~b} .15 \mathrm{c}, \mathrm{lb} .50 \mathrm{c}$ 


\section{Seedlings.}

ASTERS.

In assorted colors, doz. $25 \mathrm{c}$, hundred $\$ 2.00$

BALSAMS.

In various colors, per doz. $25 \mathrm{c}$

CALENDULAS.

per doz. $25 \mathrm{c}$

CASTOR OIL BEANS.

From pots,

each $5 \mathrm{c}$, doz. $50 \mathrm{c}$

cosmos.

Early Flowering,

per doz. $25 \mathrm{c}$

CARNATIONS.

Marguerite, from pots,

each $5 \mathrm{c}$, doz. $50 \mathrm{c}$

LOBELIAS.

Blue; fine for baskets and beds,

each $5 \mathrm{c}$, doz. $50 \mathrm{c}$

MARIGOLDS.

Pride of the Garden,

Double French,

per doz. $25 \mathrm{c}$ per doz. $25 \mathrm{c}$

NASTURTIUMS.

Dwarf, from pots,

each $5 \mathrm{c}$, doz. $30 \mathrm{c}$

Tall, from pots, each $5 \mathrm{c}$, doz. $30 \mathrm{c}$

\section{PANSIES.}

Large flowering, mixed, doz. $25 \mathrm{c}$, hundred $\$ 2.00$

PHLOX DRUMMONDI.

In various colors,

per doz. $25 \mathrm{c}$

SNAPDRAGON.

White, yellow and red. From pots, each $5 \mathrm{c}$, doz. 50c TEN=WEEKS STOCKS.

Various colors, per doz. $25 \mathrm{c}$

ZINNIAS.

Various colors, per doz. $25 \mathrm{c}$ 

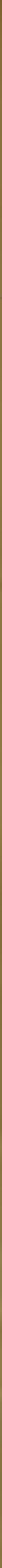